\title{
АНГЛОСРПСКИ КАО ЈЕЗИЧКИ ИЗАЗОВ ЗА БУДУЋНОСТ СРПСКОГ ЈЕЗИКА
}

\section{Сажетак}

Лексика српског језика убрзано се мења под све већим утицајем дигиталних медија додавањем нових речи и израза. Уплив англицизама је, са једне стране, природан вид богаћења лексике српског језика, међутим постоји и дугорочна опасност да ће туђице драматично променити структуру језика. Овакав утицај огледа се у синдрому миленијумске бубе, који је први дефинисао Твртко Прћић. Посредством дигиталних медија, појава миленијумске бубе усталила се као нешто потпуно природно у комуникацији путем интернета, али и ван њега. Примери англосрпског могу се наћи свуда на интернету, почевши од наслова страница, преко буквалног превођења израза, језичких конструкција, огласа и читавих сајтова, до крајње безазлених позајмљеница на интернету, које заједнички чине да српски језик на интернету буде угрожен.

Циљ овог рада јесте приказивање тренутне ситуације везане за коришћење англосрпског, указивање на могуће дугорочне последице по српски језик у будућности, као и представљање могућих решења за овај проблем. Резултати истраживања показали су да је тенденција коришћења енглеских конструкција и англицизама у све већем порасту, као и да се они, иако неприлагођени српском језику, користе у истој мери и да у сличним ситуацијама замењују српске конструкције.

Кључне речи: англосрпски језик, лексика, синдром миленијумске бубе, англицизми.

1 Филозофски факултет, Ћирила и Методија 2, Ниш 18000

donpedjas@gmail.com 


\section{1. Увод}

Језгро лексике српског књижевног језика представљају речи (лексеме) пореклом из вуковског народног српског језика, док њен фонд повећавају и богате туђице - речи из страних језика. То је природан процес унутар језика, који се одликује сопственом дијалектиком, али се уданашње време, захваљујући развоју науке и технике чини да се те промене брже догађају и јасније уочавају. Иако постоји јасна потреба за новим речима (по свом пореклу, то су најчешће англицизми) које би описале нове уређаје, њихове карактеристике као и нове елементе у пословању, образовању и другим областима, намеће се питање како, у којој мери и на који начин усвајати те нове речи. Сједињене Америчке Државе су данас највећа информатичка и технолошка сила, па стога не чуди чињеница да је највећи број нових речи и термина управо на енглеском језику. Самим тим, и најчешће усвајани термини углавном имају англофоно порекло. То је, са једне стране, природан вид богаћења лексике српског језика, јер се путем језичких контаката на скоро свим нивоима нове речи уврштавају у лексикон ради попуњавања одређених језичких празнина. У већини случајева, позајмљују се речи које немају одговарајући еквивалент, па се самим тим оне користе као одомаћене речи. Али, све је заступљенији тренд позајмљивања речи за које постоје српски пандани, што може представљати језичку опасност. Такве речи обично преузимају не само значење, већ у потпуности замењују одређене термине из српског језика.

Успон енглеског као језика међународне иинтернет-комуникације утицао је слично и на друге европске језике. Успоставивши се као lingua franca у готово свим областима комуникације, новостворени социолингвистички статус енглеског језика омогућио је да се енглески посматра као глобални језик (Crystal 2003), а недавно код нас и као нативизовани страни језик (Prćić 2014). Општи циљ овог истраживања био је да испита статус енглеског језика у српском, као и да укаже на новонастале трендове коришћења енглеских речи и конструкција уместо српских. Под статусом овог језика мисли се на употребу енглеског језика у свакодневном приватном и професионалном животу, као и на све чешћу комуникацију путем дигиталних медија. 


\section{2. Теоријски оквир}

Узимајући у обзир тренутну улогу енглеског као глобалног језика (Crystal 2003), језичке заједнице све се више суочавају са потребом за језичком стандардизацијом у погледу прилагођавања лексичких позајмица из енглеског језика. С обзиром на то да се лексичке позајмљенице из енглеског у српском прилагођавају преобликовањем (преузимањем новог облика и њему придружене нове садржине (Prćić 2011: 124) и превођењем, није ретко да поједини концепт има неколико имена на српском језику. Тако се српски све више суочава са захтевом за језичком стандардизацијом у погледу прилагођавања лексичких позајмљеница са енглеског језика. Последњих деценија, српски је био изложен неконтролисаном приливу енглеских речи, нарочито нових кованица и термина, због чега је дошло до јаке потребе за добром језичком политиком како би се утврдило које су лексичке позајмљенице из енглеског на српски оправдане $и$, ако јесу, како их треба прилагодити српском. Што се тиче српске терминологије позајмљеница, генерално се може рећи да је у последњих неколико деценија у великој мери зависила од енглеског, јер се ствара позајмљивањем и превођењем енглеских неонима, као и њихових колокација на српски језик. Као резултат тога, одређени број недавних студија бавио се питањима енглескосрпских контаката, иако се питање енглеских термина на српском језику углавном изучава у оквиру опште лексике српског језика (Bugarski 1996; Filipović 1986; Klajn 2006; Mišić Ilić i Lopičić 2011; Prćić [2005], 2011; Vasić, Prćić i Nejgebauer [2001], 2011). Поред потребе за одређеном обимом прескриптивизма, англицизација не-енглеских језика створила је потребу за изградњом контактних језичких компетенција, која укључује три међусобноповезанеметоде:употребу језика, опис језика ипрескрипцију, као и наставу језика (Prćić 2014: 150).

\section{3. Језици у контакту}

Рудолф Филиповић у делу Теорија језика у контакту покушава да покаже да је утицај енглеског толико велики да „данашњи читалац или слушалац не мора бити лингвиста у тексту или говору својих саговорника примети да, иако је то текст или говор на његовом матерњем 
језику, се јављају речи и изрази који не припадају том језику, већ су преузети из другог језика“. Многе појаве не могу се решити једноставним поређењем структуре два језика који ступају у контакт: узимајући у обзир прилично сложене социолошке, културолошке и разне друге елементе, лингвисти су успели да пронађу тачније одговоре на питања везана за језичко позајмљивање. Кроз овај, другачији поглед на проблематику језика у контакту, постало је очигледно да позајмљивање није само пренос елемената (речи, израза, реченичних конструкција) из једног језика у други, већ и адаптација на фонолошком, морфолошком и семантичком нивоу.

Услед великог броја англицизама који су се недавно појавили у српском језику у кратком временском року, појавила се и потреба да се они класификују на више начина и из више углова. Твртко Прћић у књизи Енглески у српском говори о неколико критеријума по којима би се англицизми у српском језику могли класификовати и детаљније описати. Англицизми се могу класификовати и одредити уз помоћ следећих параметара: начин настанка, реализације, оправданости и статуса (Прћић 2005: 119-143).

\section{4. Англосрпски језик}

Поменути аутор истиче да смо сведоци „јединственог језичког, социолошког и културолошког феномена који је попримио сва обележја језичке англоманије и постао веома препознатљив статусни симбол" (Прћић 2005: 77). Овакав, самоук и несистематичан начин учења страних речи има за последицу усвајање појединих речи, структура, па и гласова, од стране говорника који ни сами нису у потпуности сигурни у њихово значење. Последица свега овога јесте известан ниво пасивног знања које омогућава само делимично разумевање општег значења тих позајмљеница. Проблем лежи у томе што се такво усвајање, ван образовног система, темељи на непотпуним, понекад и нетачним информацијама, па уместо да служи допуњавању знања стечених у школи, неретко га потискује и квари језик. Све ово показује да енглески у српском тренутно има већи значај него било који други страни језик и служи као допунски језик. Што се тиче самог јављања ен- 
глеског језика у српском, оно може бити унутар, поред и изнад српског. Лако је проценити да се у случају гејмерског социолекта енглески језик све више јавља изнад српског тако што потискује не само српске речи већ и граматику, мада се углавном због недовољног знања говорника истовремено користе правила оба језика. Прћић још истиче и да је „једна од најупадљивијих и најбитнијих последица све бројнијих утицаја енглеског језика на српски, која проистиче из његове функције допунског језика, постепена хибридизација српског језика“. Он додаје да се оваква појава може назвати англосрпски језик, који дефинише као „социолект [...] својствен [...] урбаним, обично двојезичним, људима млађе генерације, започетог а незавршеног образовања, који своју језичку и другу културу стичу углавном путем популарних мас-медија“ (Прћић 2000: 872). По њему, овај хибридни, англосрпски језик јесте „врста српског језика који (све више) одступа од својих норми и (све више) бива употребљаван према нормама енглеског језика - захваљујући, у првом реду, “површинским преводиоцима'” (Исто). Па ипак, аутор опомиње да се не може сваки утицај енглеског језика на српски назвати англосрпски, већ само оно што чини неоправдане и непотребне иновације настале под утицајем енглеске норме.

\section{5. Други облици утицаја енглеског на српски језик}

Према Б. М. Илић, можемо разликовати два варијетета српског језика настала под утицајем енглеског - англосрпски и серглиш (Serblish, Serglish). Обе варијанте првенствено користи градско становништво, па их можемо посматрати као специфичне урбане дијалекте. Једна од разлика је та да се англосрпски употребљава у српској говорној средини, а серглиш у дијаспори. Међутим, имајући у виду, пре свега, да се и англосрпски и серглиш користе у специфичним друштвеним ситуацијама и да осликавају разлике између појединих друштвених средина и група, најупутније би било посматрати их као социолекте. Што се тиче функционалног аспекта, ауторка додаје да „избор и употреба одређених језичких средстава која представљају англицизме у најширем смислу те речи у вези са посебним потребама говорника које намећу домен, ситуација, професија 
или тематика, па их тако можемо постматрати и као карактеристике неких посебних функционалних стилова, рецимо, језика рекламе или медија". Могуће је да се ово исто може рећи за језик гејмера јер он делом припада интернет социолекту, а серглиш се користи углавном на интернету. Она додаје да се „може се претпоставити да је у случају англосрпског на делу језичко позајмљивање, док се у случају серглиша ради о промени кодова“. Узимајући све то у обзир, тешко је одлучити да ли гејмерски социолект спада у варијетет англосрпског или серглиша јер поседује карактеристике оба. У току играња гејмери се повезују на интернет, који је сасвим другачија средина од оне у којој живе и где српски није главни језик и самим тим долази до промене кодова, а због превеликог језичког позајмљивања не може се рећи да говоре чистим српским језиком (Илић, Б. М 2011: 72).

\section{6. Синдром миленијумске бубе}

Синдром миленијумске бубе лексичка је појава чији термин потиче из домена програмирања - наиме, догодила се грешка у програмирању старих рачунара, након које они више нису успевали да препознају и обраде датуме после 31.12.1999. Тај bug с почетка новог миленијума, који на српски преводимо као грешку, али и као бубу, у овом другом преводу добија саркастичне обрисе, где се у метафоричној синтагми миленијумска буба имплицитно указује на опасност и подмуклост нечег наизглед безопасног и ситног, али нечег што у кратком временском року успева да се намножи и постане велика опасност.

Опасност од миленијумске бубе огледа се у несвесном прихватању утицаја енглеског језика на српски на фонолошком, морфолошком и синтаксичком плану, те грађења тзв. англосрпског језика. Твртко Прћић истиче три етапе испољавања синдрома миленијумске бубе: лансирање, ширење и прихватање (Прћић 2000: 869). Лансирање представља директно пресађивање речи или израза у току превођења са енглеског на српски језик; ширење је несвесно вишеструко понављање у масовним медијима, нарочито опасно због свог психолошког механизма - њему је подложан велики број људи, којима нешто услед понављања трајно остаје забележено у подсвести и као такво потпуно природно; прихватање јесте 
механизам који такође рачуна на несвесно усвајање и коришћење онога што, заправо, није природно српском језику.

То неприродно, а глобално имплементирање видљиво је у синтаксичким конструкцијама које говорници српског језика свакодневно користе. Прћић наводи неке од примера: “Могу ли да вам помогнем?”, према: "Can I help you?"; “Моје име je”, према: “My name is"; "кратка прича”, према: "short story" (Прћић 2000: 868-869) итд. Уплив англицизама на лексичком нивоу најтипичнији је и најуочљивији утицај енглеског на српски. Много је опасније ово несвесно прихватање синтаксичких конструкција, али и морфолошко адаптирање, попут поменутог bug y: баговање, где у тзв. калкирању говорници српског језика деривирају нову домаћу реч помоћу типичног начина грађења (bug-ова-ње) речи у српском. Дугорочно, такве појаве могу довести до осиромашења лексикона српског језика домаћим речима словенског порекла, јер говорници олако прихватају нове, туђе, и притом се према њима опходе као да су се увелико и одавно одомаћиле. Слично се дешава и на фонолошком плану, где уписању (можда и говору) може доћи до замене гласова у духу енглеског језика, а ова појава подсећа и на грешке у средњовековној преписивачкој традицији, која је умногоме утицала на ток развоја данашњег српског језика. У ком ће смеру тећи кретања и промене условљене миленијумском бубом показаће време.

\section{7. Примери англосрпског језика}

Ширење енглеског језика обично значи усвајање енглеског као другог у различитим деловима света. Ипак, што се тиче актуелне ситуације контакта између енглеског и српског језика, енглески језик има положај првог страног језика. Међутим, за разлику од других страних језика који се првенствено користе у формалним ситуацијама, то јест за комуникацију са говорницима из других земаља, енглески језик у Србији користи се не само за међународну јавну комуникацију и преузимање нових термина, већ и за комуникацију између самих говорника српског језика, нарочито међу младим људима у урбаним срединама, такозваним глобалним тинејџерима (Schwartz 1996: 1201), који су посебно наклоњени коришћењу англицизама и све више фраза на енглеском језику. 
Српски интернетски форуми, нарочито они намењени млађој популацији, обилују енглеским позајмљеницама, као и реченицама у којима је приметно пребацивање кодова, па самим тим енглески постаје ознака глобалног идентитета младих. Чим се разговор дотакне одређене теме, на пример игрица, моде на интернету или нивоа формалности, може доћи до мањег или већег аутоматског пребацивање кода (Gerlach 2003: 33).

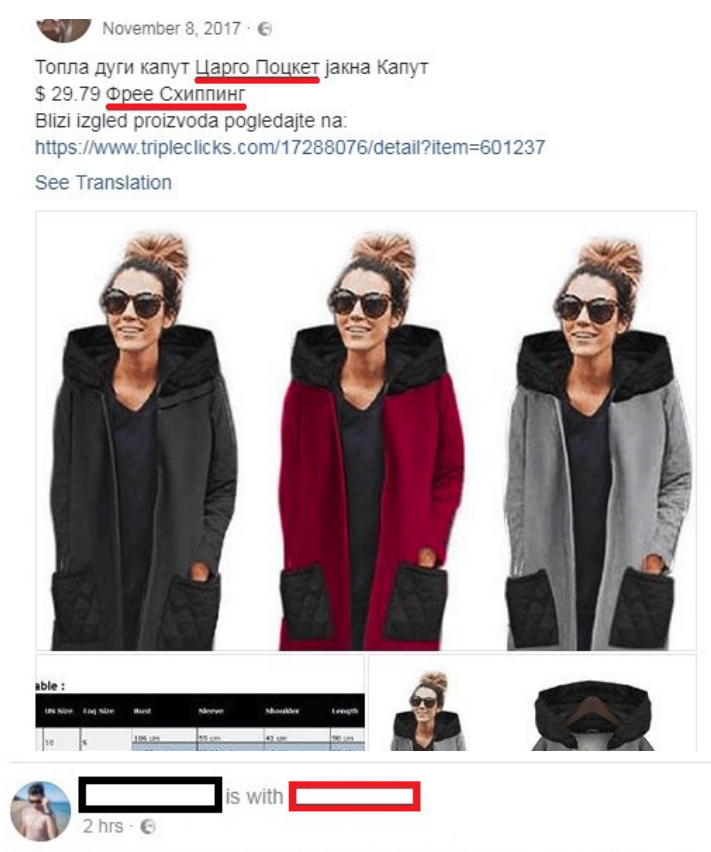

Šta je to Bitcoin, šta majnovanje a šta kriptovaluta? Može li se od ovoga zaraditi? Saznajte u novom DESNOM KLIKU!

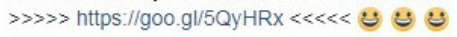

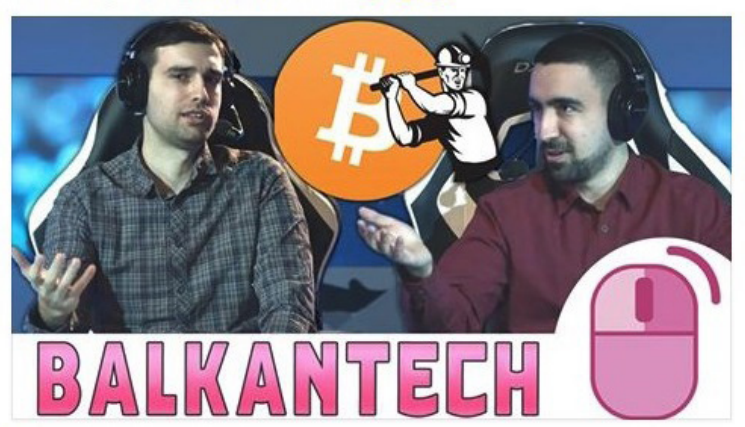

Слике 1 и 2. Примери англосрпског на интернету 
Такође, важно је додати да су се овом темом бавили и настављају да се баве други истраживачи. Важно је поменути Du yu speak anglosrpski? Речник новијих англицизама Твртка Прћића. Поред тога, примери коришћења англосрпског у текстовима могу се наћи и на линку http://www.ljubodraggrujic.com/texts/angloserbian texts. htm, као и на многим интернет форумима.

\section{8. Закључак}

Односи између два језика нису увек најјаснији и временом се мењају. Контрастивном анализом два језика, у овом случају енглеског и српског, утврђује се какав и колики утицај један језик има на други. Многа ранија истраживања потврдила су да енглески има много већи утицај на српски, па самим тим утиче и на његову структуру. Пракса је показала да англицизми почињу да се употребљавају не само у већој мери него пре, него и да се све мање прилагођавају систему српског језика. Постоји бојазан да ће се у будућности из енглеског позајмљивати читаве фразе директно, без прилагођавања, па ће млади људи почети да користе неку варијанту англосрпског, а не српски књижевни језик.

Поузданог решења за овај проблем нема. Ипак, може се рећи да је велика одговорност на преводиоцима, који текстове са енглеског (прототекстове) морају преводити најпре водећи рачуна о садржини, тј. адекватности одабраног лексичког еквивалента у српском језику, али потом, не са мање пажње, и о томе да преведени текст (метатекст) буде у духу српског језика. Тиме се остварују језичке, културолошке, књижевне или научне (у зависности од природе текста) везе између два народа, али са што мање опасности од угрожавања језичког идентитета оног другог, јер је језик, свакако, једно од најважнијих обележја идентитета једног народа. Вуковски речено: све док живи један језик, живеће и његов народ. 


\section{Извори и литература}

Bugarski, Ranko. (1996). Lingvistika u primeni. [Linguistics in Application]. Beograd: Čigoja štampa.

Crystal, David. (2003). English as a global language (2nd ed.). Cambridge: Cambridge University Press.

Filipović, Rudolf. (1986). Teorija jezika u kontaktu. Uvod u lingvistiku jezičkih dodira. [Theory of Languages in Contact. An Introduction to Linguistics of Language Contacts]. Zagreb: Jugoslovenska akademija znanosti i umjetnosti - Školska knjiga.

Gerlach, Manfred (2003). English Words Abroad. Amsterdam/Philadelphia. John Benjamins (Terminology and Lexicography Research and Practice. vol. 7).

Klajn, Ivan. (2006). "Neologisms in Present-day Serbian". International Journal of the Sociology of Language 2001 (151), 89-110.

Mišić Ilić, Biljana. (2011). "Anglosrpski i serglish: dva varijeteta srpskog jezika nastala pod uticajem engleskog". Vera Vasić (ur). Primenjena lingvistika u čast Ranku Bugarskom: Jezik u upotrebi / Language in Use, međunarodni zbornik. 71-93.

Mišić Ilić, Biljana i Lopičić, Vesna. (2011). "Pragmatički anglicizmi u srpskom jeziku [Pragmatic Anglicisms in Serbian]." Zbornik Matice srpske za filologiju i lingvistiku 54 (1): 261-273.

Prćić, Tvrtko. (2005) 2011. Engleski u srpskom, drugo izd. [English within Serbian] (2nd ed.). Novi Sad: Filozofski fakultet.

Prćić, Tvrtko. (2014). Building contact linguistic competence related to English as the nativized foreign language. System, 42, 143-154. Преузето ca: http://www.sciencedirect.com/science/article/pii/S0346251X13001735. doi: 10.1016/j.system.2013.11.007

Schwarz, P. (1996). The Art of the Long View. New York: Doubleday.

Vasić, Vera, Prćić, Tvrtko i Nejgebauer, Gordana. (2001). Du yu speak anglosrpski? Rečnik novijih anglicizama (2. izd) [Du Yu Speak AngloSerbian? A Dictionary of Recent Anglicisms in Serbian] (2nd ed.). Novi Sad: Zmaj.

Прћић, Твртко. (2000). “О синдрому миленијумске бубе и језику англосрпском". Јужнословенски филолог, LVI, Београд, 2000, 867-873. 


\author{
Predrag Ilić \\ Milica Aleksić
}

\title{
ANGLO-SERBIAN AS A LINGUISTIC CHALLENGE FOR THE FUTURE OF THE SERBIAN LANGUAGE
}

\section{Summary}

The lexicon of the Serbian language is rapidly changing under the ever increasing influence of digital media by addition of new words and expressions. The influence of anglicisms can, on the one hand be viewed as a form of enriching the lexicon of the Serbian language, but on the other there is also a danger from loanwords which can dramatically change the structure of the language.This influence is reflected in the "millennium bug" syndrome, which was first defined by Trrtko Prćić. Through digital media, the phenomenon of millennium bug has established itself as something completely natural in communication over the Internet, but also outside of it. Examples of Anglo-Serbian can be found everywhere on the internet, ranging from page titles, through literally translating terms, language constructions, ads and entire websites, to extremely harmless loanwords on the Internet, which combined threaten the Serbian language on the Internet.

The aim of this paper is to present the current situation regarding the use of Anglo-Serbian, to point out the possible long-term consequences for the Serbian language in the future, and to present possible solutions to this problem. The results of the research have shown that the tendency of using English constructions and anglicisms is increasing, and that those, although unadjusted to the Serbian language, are used in the same way and in similar situations instead of Serbian constructions.

Key words: Anglo-Serbian language, lexicon, millennium bug syndrome, anglicisms. 